\title{
Analisis Bangkitan Perjalanan Penduduk Pada Kompleks Perumahan Taman Sudiang Indah
}

\author{
Dane Cheber Yusmar Tandioga*1, Rais Rachman *2, Louise Elizabeth Radjawane*3 \\ *1 Mahasiswa Teknik Sipil, Fakultas Teknik, Universitas Kristen Indonesia Paulus, Makassar, \\ Indonesia dane.cheber@gmail.com \\ *23 Dosen Teknik Sipil, Fakultas Teknik, Universitas Kristen Indonesia Paulus, Makassar, Indonesia \\ rais.rachman@gmail.com dan eliz_louise@yahoo.com
}

Corresponding Author: eliz_louise@yahoo.com

\begin{abstract}
Abstrak
Perumahan Taman Sudiang Indah Kecamatan Biringkanaya Kelurahan PAI terletak di pinggiran kota Makassar dengan jumlah penduduk \pm 2.619 jiwa akan menimbulkan bangkitan perjalanan. Perumahan memunculkan bangkitan - bangkitan perjalanan penduduk yang bisa membebani jalur - jalur jaringan jalan menuju tempat beraktivitas. Penelitian dilakukan untuk mengetahui karakteristik rumah tangga dan karakteristik perjalanan rumah tangga serta memodelkan bangkitan perjalanan di perumahan Taman Sudiang Indah.Survei ini dilakukan dengan cara mengisi kuisioner di dalam google form. Menganalisis data dengan metode statistik deskriptif uji korelasi dan regresi linear berganda. Hasil penelitian menunjukkan faktor mempengaruhi bangkitan perjalanan pada kompleks perumahan Taman Sudiang Indah adalah penghasilan rata-rata keluarga $\left(\mathrm{X}_{4}\right)$, jumlah anggota keluarga bekerja $\left(\mathrm{X}_{5}\right)$, dan jumlah anggota keluarga bersekolah/kuliah $\left(\mathrm{X}_{6}\right)$ terhadap jumlah bangkitan $(\mathrm{Y})$. Model persamaan bangkitan perjalanan untuk perumahan Taman Sudiang Indah adalah $\mathrm{Y}=1.2730+0.095$ $\mathrm{X}_{4}+0.371 \mathrm{X}_{5}+0.273 \mathrm{X}_{6}$, nilai koefisien determinasi $\left(\mathrm{R}^{2}\right)$ sebesar $25,3 \%$ dan nilai koefisien korelasi (R) sebesar $50,3 \%$.
\end{abstract}

Kata Kunci: Bangkitan, Perumahan, Penduduk, Regresi, Karakteristik Perjalanan

\begin{abstract}
Taman Sudiang Indah Residence, Biringkanaya Subdistrict, PAI Village is located on the outskirts of Makassar City with a population of $\pm 2,619$ people which will cause travel. Residential generation trip generation for residents who can be lazy on the road network to the place of activity. This research was conducted to determine household characteristics and household travel characteristics and to model trip generation in Taman Sudiang Indah residence estate.This survey was conducted by filling out a questionnaire in google form. Analyzing the data with descriptive statistical methods of correlation test and multiple linear regression. The results showed that the factors influence trip generation in the Taman Sudiang Indah residence complex were the average family income (X4), the number of working family members (X5), and the number of family members attending school/college $\left(\mathrm{X}_{6}\right)$ to the number of generation $(\mathrm{Y})$. The trip generation equation model for Taman Sudiang Indah residence is $\mathrm{Y}=1.2730+0.095 \mathrm{X}_{4}+0.371 \mathrm{X}_{5}+0.273 \mathrm{X}_{6}$, the value of the coefficient of determination $\left(\mathrm{R}^{2}\right)$ is $25.3 \%$ and the value of the correlation coefficient $(\mathrm{R})$ is $50.3 \%$.
\end{abstract}

Keywords: generation, residence, regression, travel characteristics

\section{PENDAHULUAN}

Transportasi timbul karena adanya pertumbuhan penduduk, peningkatan pendapatan, peningkatan kepemilikan kendaraan, dan fasilitas-fasilitas lainnya. Hal yang harus diperhatikan adalah semakin banyak jumlah dan jenis kendaraan yang beroperasi semakin besar pula bangkitan perjalanan [1]. 
Kota Makassar salah satu kota metropolitan terbesar di kawasan Indonesia Timur yang mempunyai luas wilayah $175,77 \mathrm{~km}^{2}$ dengan jumlah penduduk \pm 1,5 juta jiwa [2]. Sebagai Ibu Kota Provinsi Sulawesi Selatan, Kota Makassar dengan aktivitas transportasi cukup tinggi. Ini terlihat pada pagi hari dan sore hari kemacetan lalulintas terjadi utamanya pada jalan- jalan sekitar wilayah perkantoran, perindustrian, pendidikan dan wilayah-wilayah pusat perbelanjaan serta wilayah yang padat perumahan.

Perkembangan perumahan pada wilayah Kota Makassar semakin bermunculan setiap tahunnya utamanya diwilayah pinggiran Kota [3]. Perkembangan perumahan seiring dengan perkembangan penduduk, hal inilah yang menarik bagi pengembang perumahan untuk berinvestasi. Perkembangan perumahan ini, maka bangkitan perjalanan dari perumahan-perumahan yang ada akan membebani jalan-jalan yang berada disekitar perumahan.

Perumahan Taman Sudiang Indah adalah salah satu perumhanan yang terletak pada Kelurahan Pai Kecamatan Biring Kanaya Kota Makassar Jumlah penduduk perumahan Taman Sudiang Indah 2.619 jiwa. Masyarakat perumahan Taman Sudiang Indah mempunyai karakteristik yang baik dari segi sosial budaya, pekerjaan maupun tingkatan pemasukan. Bangkitan perjalanan yang dilakukan oleh sejumlah masyarakat perumahan Taman Sudiang Indah akan menimbulkan kemacetan pada jalan Poros Makassar - Maros. Prumahan ini terdiri dari 7 Blok.

Menurut Miro (2005) bangkitan perjalanan dapat diartikan sebagai besar atau banyaknya perjalanan dari kawasan atau zona tertentu dalam lingkup perkotaan menuju ke kawasan atau zona tertentu untuk melakukan berbagai bentuk aktivitas [4][5]. Sedangkan Ortuzar dan Willumsen (2001) mendefinisikan bangkitan perjalanan sebagai jumlah perjalanan dari zona tertentu, yang berupa perumahan, perkantoran, pusat-pusat bisnis, industri, lokasi wisata, dan tempat beraktivitas lainnya [6].

Pemodelan bangkitan perjalanan dapat dilakukan melalui beberapa pendekatan. Pendekatan yang umum digunakan untuk pemodelan bangkitan pergerakan adalah dengan menggunakan analisis regresi. Untuk menganalisis parameter terbaik yang memiliki hubungan signifikan terhadap terjadinya suatu bangkitan perjalanan dari perumahan pada penelitian ini digunakan metode regresi linier berganda. Pada model regeresi linier berganda, variabel yang akan diramalkan (dependent variable) memiliki hubungan secara linier dengan variabelvariabel bebasnya (independent variables). Secara matematis, hubungan tersebut dapat diformulasikan sebagai berikut [7];

$$
\mathrm{Y}=\mathrm{bo}+\mathrm{b} 1 \mathrm{X} 1+\mathrm{b} 2 \mathrm{X} 2+\ldots+\mathrm{bn} \mathrm{X}
$$

Penelitian - penelitian sebelumnya tentang analisis bangkitan dan tarikan pergerakan pada suatu tata guna lahan yang digunakan oleh penulis sebagai refrensi dalam melakukan penelitian ini dinataranya Model Bangkitan Perjalanan Komuter Pinggiran Kota Makassar (Studi Kasus Perumahan Tirasa Pratama) [8]. Studi Bangkitan Pergerakan Komuter Pada Perumahan Berlokasi Di Pinggiran Kota Makassar [9]. Analisis Bangkitan Perjalanan Berbasis Rumah Tangga pada Perumahan Bumi Tamanlarea Permai Kota Makassar [10]. Bangkitan Perjalanan Penduduk di Kecamatan Alak Kota Kupang [11]. Bangkitan Perjalanan Rumah Tangga Di Kecamatan Darussalam Kabupaten Aceh Besar [12].

Tujuan penelitian adalah untuk memodelkan bangkitan perjalanan pada perumahan Taman Sudiang Indah. Metode statistik deskriptif uji korelasi dan regresi linear berganda. lokasi yang menjadi objek penelitian, yaitu blok D, E, F, dan G. Variabel-variabel penelitian yaitu Jumlah Bangkitan, jumlah anggota keluarga, jumlah kepemilikan kendaraan roda 2 (dua) sepeda motor, jumlah kepemilikan kendaraan roda 4 (empat) mobil pribadi, penghasilan rata - rata keluarga, umlah anggota keluarga bekerja dan jumlah anggota keluarga berskolah/kampus. 


\section{METODE PENELITIAN}

\section{Lokasi Penelitian}

Lokasi penelitian kompleks perumahan Taman Sudiang Indah khususnya blok D, E, F, dan G.

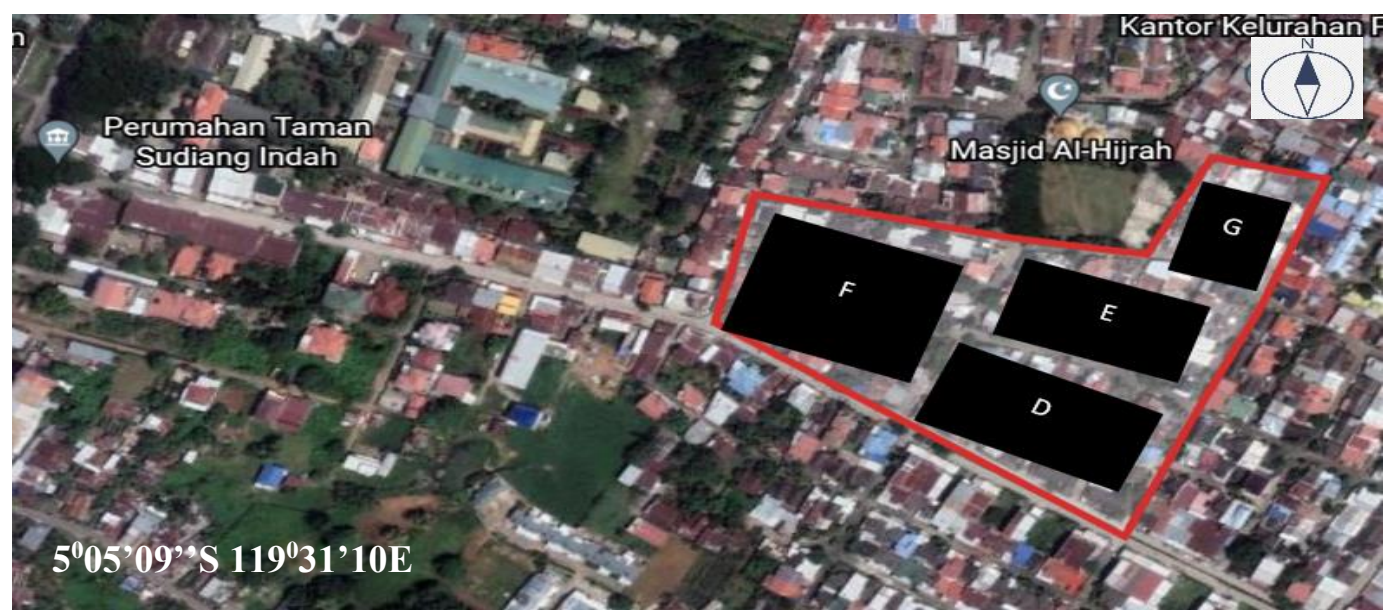

Gambar 1. Lokasi Penelitian

\section{Pengumpulan Data}

Pengumpalan data penelitian menggunakan kuisioner disebar secara online, data tersebut dibedakan menjadi dua berdasarkan sumber data:

\section{a. Data Primer}

Data primer merupakan data yang dicari dan dikumpulkan dalam penelitian dengan cara memberikan kuisioner secara online kepada satuan rumah pada blok D, E, F dan G Taman Sudiang Indah. Data yang dikumpulkan merupakan pertanyaan mengenai karakteristik perjalanan yang ditujukan kepada setiap individu dalam keluarga.

Pelaksanaan pengambilan kuisioner dilakukan dengan cara berikut :

- Kuisioner dibagikan melalui google form.

- Kuisioner dibagikan kepada setiap rumah sesuai jumlah anggota keluarga yang telah berusia 5 tahun ke atas dengan pertimbangan pada usia tersebut telah melakukan perjalanan.

- Setelah kuisioner diisi maka kuisioner tersebut dirangkumkan menjadi sebuah data per blok perumahan.

b. Data Sekunder

Data sekunder diperoleh dari kantor kelurahan Pai, berupa data - data :

- Struktur Kependudukan (Jumlah Penduduk)

- Peta Administratif lokasi penelitian

\section{Teknik Pengambilan Data}

Populasi penelitian adalah seluruh rumah yang berada di blok D, E, F dan G Taman Sudiang Indah. Mengetahui besar sebuah data diambil, jumlah penduduk sebanyak 167 Kartu Keluarga (KK). Populasi penduduk tersebut pada blok D terdapat $36 \mathrm{KK}$, pada blok E terdapat $45 \mathrm{KK}$, pada blok F terdapat $60 \mathrm{KK}$ dan pada blok $\mathrm{G}$ terdapat $26 \mathrm{KK}$.

Menentukan jumlah data diteliti menggunakan Rumus Slovin : 


$$
\begin{aligned}
& \qquad n=\frac{\mathrm{N}}{1+\left(\mathrm{N} *(e)^{2}\right.} \\
& =\frac{167}{1+\left(167 *(5 \%)^{2}\right.} \\
& n=117,8130 \text { dibulatkan } 118 \text { unit }
\end{aligned}
$$

Dimana:

$\mathrm{n}=$ sampel

$\mathrm{N}=$ total populasi

$\mathrm{e}=$ toleransi $(5 \%)$

\section{Variabel Penelitian}

Menghindari penafsiran ganda terhadap variabel - variabel maka perlu dilakukan pendefinisian variabel sebagai berikut :

$\mathrm{Y}=$ Jumlah Bangkitan

$\mathrm{X}_{1}=$ Jumlah Anggota Keluarga

$\mathrm{X}_{2}=$ Jumlah Kepemilikan Kendaraan Roda 2 (dua) Sepeda Motor

$\mathrm{X}_{3}=$ Jumlah Kepemilikan Kendaraan Roda 4 (empat) Mobil Pribadi

$\mathrm{X}_{4}=$ Penghasilan Rata - Rata Keluarga

$\mathrm{X}_{5}=$ Jumlah Anggota Keluarga Bekerja

$\mathrm{X}_{6}=$ Jumlah Anggota Keluarga Berskolah/Kampus.

\section{Analasis Data}

Metode analisis data adalah cara analisis regresi linear berganda menggunakan perangkat lunak Statistic Program for Special Science (SPSS). Menganalisis data beberapa tahapan uji statistik dilakukan agar model bangkitan perjalanan dihasilkan :

a. Analisis Regresi

Metode Analisis Regresi (MAR). Pengolahan data menggunakan MAR dilakukan dengan bantuan program Statistic Program for Special Science (SPSS).

b. Analisis Karakteristik Penduduk

Analisis karakteristik penduduk mengelompokkan data yang dilakukan cara memproses data didapatkan melalui survei dalam kuisioner google form.

c. Analisis Bangkitan Perjalanan

Analisis bangkitan perjalanan (trip generation) berhubungan penentuan jumlah perjalanan keseluruhan dibangkitkan oleh suatu perumahan. Aktivitas kegiatan manusia sehari - hari berperan dalam menciptakan perjalanan.

\section{HASIL DAN PEMBAHASAN}

\section{Jumlah Anggota Keluarga}

Hasil Tabel 1 membuktikan jumlah anggota keluarga yang tertinggi di perumahan Taman Sudiang Indah 1-4 (satu-empat) orang blok D persentase sebesar 67,857 \%, hasil jumlah anggota keluarga terendah di perumahan Taman Sudiang Indah blok G persentase sebesar 42,105\%. Hasil jumlah anggota keluarga tertinggi di perumahan Taman Sudiang Indah 5-7 (lima-tujuh) orang blok G persentase sebesar 57,895 \%. 
Tabel 1. Jumlah Anggota Keluarga

\begin{tabular}{cccccc}
\hline \multirow{2}{*}{ No. } & \multirow{2}{*}{$\begin{array}{c}\text { Blok \& Tipe } \\
\text { Rumah }\end{array}$} & \multicolumn{2}{c}{ Anggota Keluarga } & \multicolumn{2}{c}{ Persentase (\%) } \\
\cline { 3 - 6 } & $\mathrm{1}-\mathbf{4}$ org & $\mathbf{5} \mathbf{- 7}$ org & $\mathbf{1 - 4}$ org & $\mathbf{5 - 7}$ org \\
\hline 1 & $\mathrm{D} / 36$ & 19 & 9 & 67,857 & 32,143 \\
\hline 2 & $\mathrm{E} / 36$ & 15 & 17 & 46,875 & 53,125 \\
\hline 3 & $\mathrm{~F} / 36$ & 20 & 19 & 51,282 & 48,718 \\
\hline 4 & $\mathrm{G} / 36$ & 8 & 11 & 42,105 & 57,895 \\
\hline
\end{tabular}

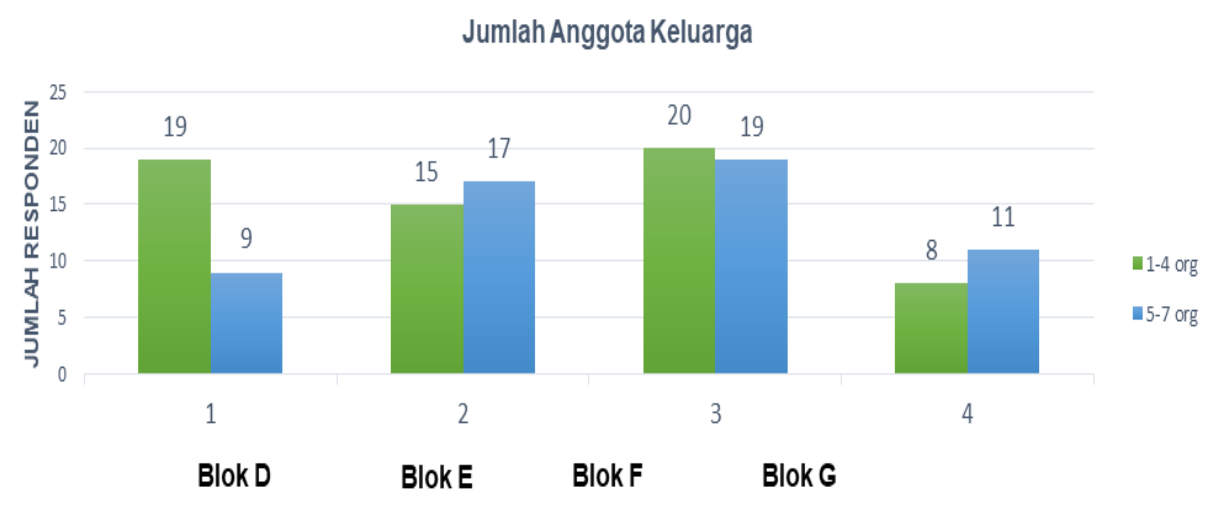

Gambar 2. Jumlah Anggota Keluarga

Hasil Tabel 2 membuktikan jumlah anggota keluarga yang bekerja tertinggi di perumahan Taman Sudiang Indah 1 (satu) orang blok $\mathrm{G}$ persentase $84,211 \%$, hasil jumlah anggota keluarga yang bekerja terendah di perumahan Taman Sudiang Indah blok F persentase 35,897 \%. Hasil jumlah anggota keluarga yang bekerja tertinggi di perumahan Taman Sudiang Indah 2 (dua) orang blok F persentase 64,103\%.

Tabel 2. Jumlah Anggota Keluarga Bekerja

\begin{tabular}{cccccccc}
\hline \multirow{2}{*}{ No. } & Blok \& & \multicolumn{3}{c}{ Keluarga Bekerja } & \multicolumn{3}{c}{ Persentase \% } \\
\cline { 3 - 8 } & tipe rumah & 1 org & 2 org & >2 orng & 1 org & 2 org & > 2 orng \\
\hline 1 & $\mathrm{D} / 36$ & 12 & 16 & 0 & 42,857 & 57,143 & 0 \\
\hline 2 & $\mathrm{E} / 36$ & 15 & 17 & 0 & 46,875 & 53,125 & 0 \\
\hline 3 & $\mathrm{~F} / 36$ & 14 & 25 & 0 & 35,897 & 64,103 & 0 \\
\hline 4 & $\mathrm{G} / 36$ & 16 & 3 & 0 & 84,211 & 15,789 & 0 \\
\hline
\end{tabular}

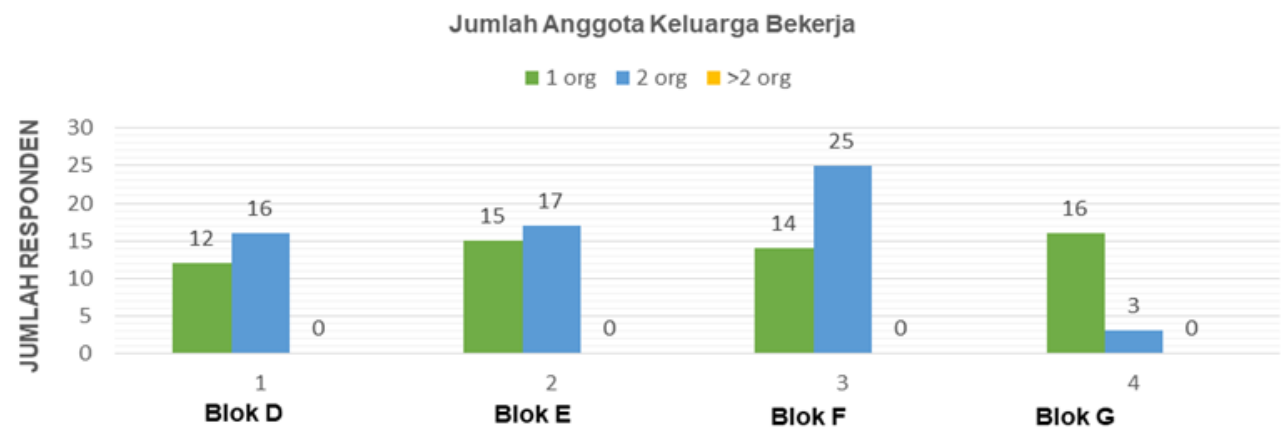

Gambar 3. Jumlah Anggota Keluarga Bekerja 
Hasil Tabel 3 membuktikan jumlah anggota keluarga yang bersekolah/kampus tertinggi di perumahan Taman Sudiang Indah 1 (satu) orang blok D sebesar 78,571\%, hasil jumlah anggota keluarga yang bersekolah/kampus terendah di perumahan Taman Sudiang Indah blok G sebesar 21,053\%. Hasil jumlah anggota keluarga yang bersekolah/kampus tertinggi di perumahan Taman Sudiang Indah 2-4 (dua-empat) orang blok G sebesar 78,947\%, hasil jumlah anggota keluarga yang bersekolah/kampus terendah di perumahan Taman Sudiang indah blok D sebesar 21,429\%. Hasil jumlah anggota keluarga yang bersekolah/kampus tertinggi di perumahan Taman Sudiang Indah >4 (>empat) orang blok F sebesar 5,128\%.

\section{Tabel 3. Jumlah Anggota Keluarga Bersekolah/Kampus}

\begin{tabular}{cccccccc}
\hline \multirow{2}{*}{ No. } & $\begin{array}{c}\text { Blok \& Tipe } \\
\text { rumah }\end{array}$ & \multicolumn{3}{c}{$\begin{array}{c}\text { Keluarga } \\
\text { Bersekolah/Kampus }\end{array}$} & \multicolumn{3}{c}{ Persentase (\%) } \\
\cline { 2 - 8 } & & $\mathbf{1}$ org & $\mathbf{2 - 4}$ org & $\mathbf{. 4}$ org & $\mathbf{1 ~ o r g}$ & $\mathbf{2 - 4}$ org & >4 org \\
\hline 1 & $\mathrm{D} / 36$ & 22 & 6 & 0 & 78,571 & 21,429 & 0 \\
\hline 2 & $\mathrm{E} / 36$ & 22 & 10 & 0 & 68,750 & 31,250 & 0 \\
\hline 3 & $\mathrm{~F} / 36$ & 18 & 19 & 2 & 46,154 & 48,718 & 5,128 \\
\hline 4 & $\mathrm{G} / 36$ & 4 & 15 & 0 & 21,053 & 78,947 & 0 \\
\hline
\end{tabular}

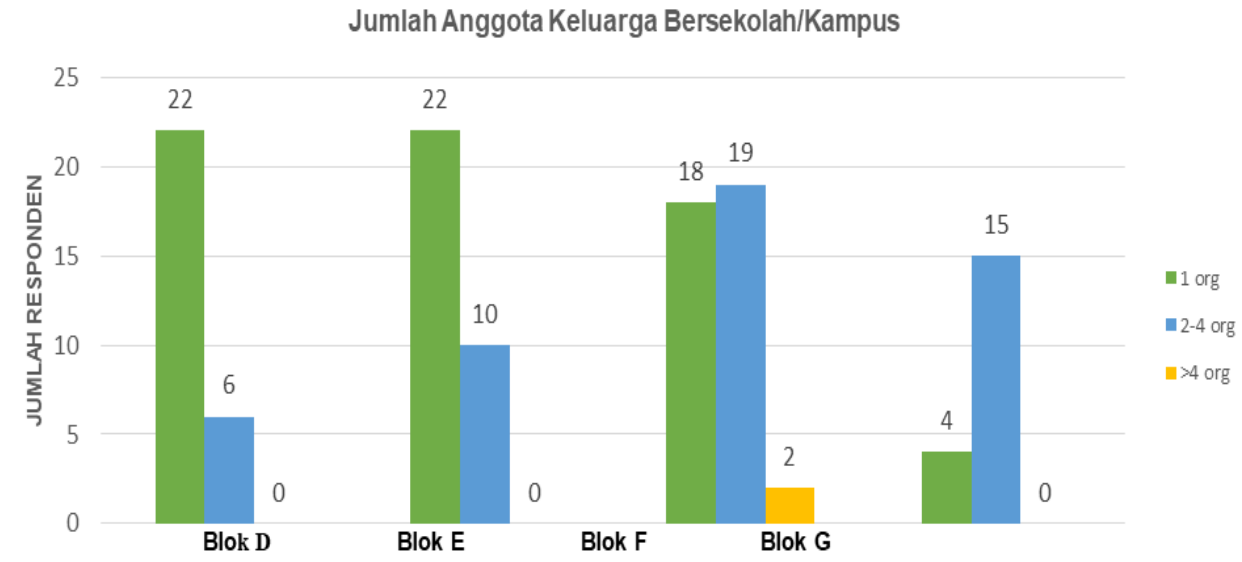

Gambar 4. Grafik Jumlah Keluarga Bersekolah/Kampus

\section{Jumlah Kendaraan Roda 2 (dua) Sepeda Motor}

Hasil Tabel 5 membuktikan jumlah kepemilikan kendaraan roda 2 (dua) sepeda motor mendominasi di perumahan Taman Sudiang Indah blok F 1 (satu) unit sebesar 94,872\%. Jumlah kepemilikan kendaraan roda 2 (dua) sepeda motor di perumahan Taman Sudiang Indah blok G 1 (satu) unit sebesar 84,211\% dan blok E 1 (satu) unit sebesar $71,875 \%$. Jumlah kepemilikan kendaraan roda 2 (dua) sepeda motor mendominasi di perumahan Taman Sudiang Indah blok D 2 (dua) unit sebesar 39,286\%.

Tabel 4. Jumlah Kepemilikan Kendaraan Roda 2 (dua) Sepeda Motor

\begin{tabular}{cccccc}
\hline \multirow{2}{*}{ No. } & $\begin{array}{c}\text { Blok \& tipe } \\
\text { rumah }\end{array}$ & \multicolumn{4}{c}{$\begin{array}{c}\text { Jumlah Kepemilikan Kendaraan Roda 2 (dua) } \\
\text { Sepeda Motor }\end{array}$} \\
\cline { 2 - 6 } & Tidak Ada & 1 Unit & 2 Unit & 2 Unit \\
\hline 1 & $\mathrm{D} / 36$ & 0 & 17 & 11 & 0 \\
\hline 2 & $\mathrm{E} / 36$ & 0 & 23 & 9 & 0 \\
\hline 3 & $\mathrm{~F} / 36$ & 0 & 37 & 2 & 0 \\
\hline 4 & $\mathrm{G} / 36$ & 0 & 16 & 3 & 0 \\
\hline
\end{tabular}




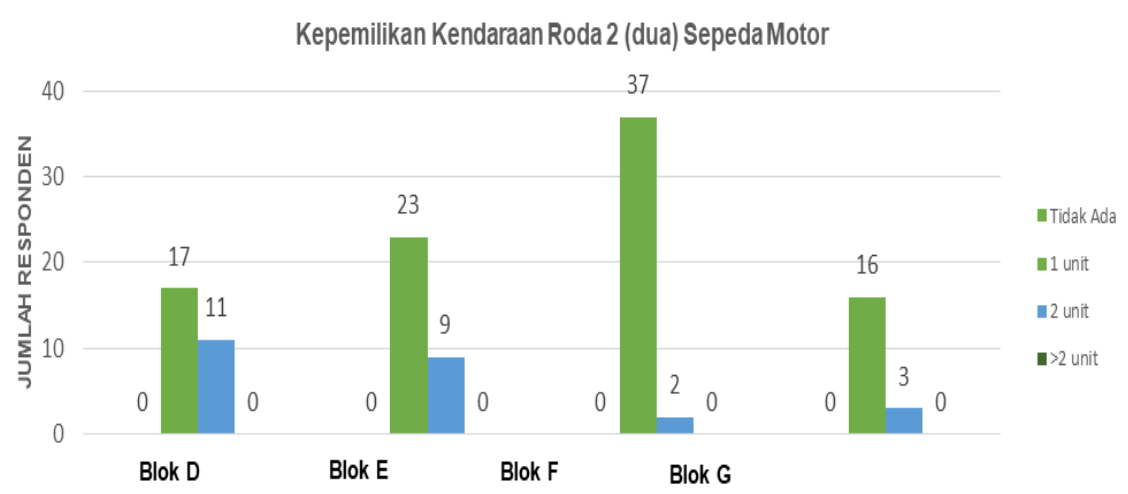

Gambar 5. Grafik Kepemilikan Kendaraan Roda 2 (dua) Sepeda Motor

\section{Kepemilikan Kendaraan Roda 4 (empat) Mobil Pribadi}

Hasil Tabel 5 membuktikan bahwa jumlah kepemilikan kendaraan roda 4 (empat) mobil pribadi yang mendominasi yaitu pada blok G 1 (satu) unit sebesar 100\%, jumlah kepemilikan kendaraan roda 4 (empat) mobil pribadi pada blok D 1(satu) unit sebesar 57,142\%, pada blok E 1 (satu) unit sebesar 53,125\% dan pada blok F 1 (satu) unit sebesar 46,153\%.

Tabel 5. Jumlah Kendaraan Roda 4 (empat) Mobil Pribadi

\begin{tabular}{cccccc}
\hline \multirow{2}{*}{ No. } & $\begin{array}{c}\text { Blok \& tipe } \\
\text { rumah }\end{array}$ & \multicolumn{4}{c}{$\begin{array}{c}\text { Jumlah Kepemilikan Kendaraan Roda 4 } \\
\text { (empat) Mobil Pribadi }\end{array}$} \\
\cline { 2 - 6 } & Tidak Ada & 1 unit & 2 Unit & >2 Unit \\
\hline 1 & $\mathrm{D} / 36$ & 12 & 16 & 0 & 0 \\
\hline 2 & $\mathrm{E} / 36$ & 15 & 17 & 0 & 0 \\
\hline 3 & $\mathrm{~F} / 36$ & 21 & 18 & 0 & 0 \\
\hline 4 & $\mathrm{G} / 36$ & 0 & 19 & 0 & 0 \\
\hline
\end{tabular}

Kepemilikan Kendaraan Roda 4 (empat) Mobil Pribadi

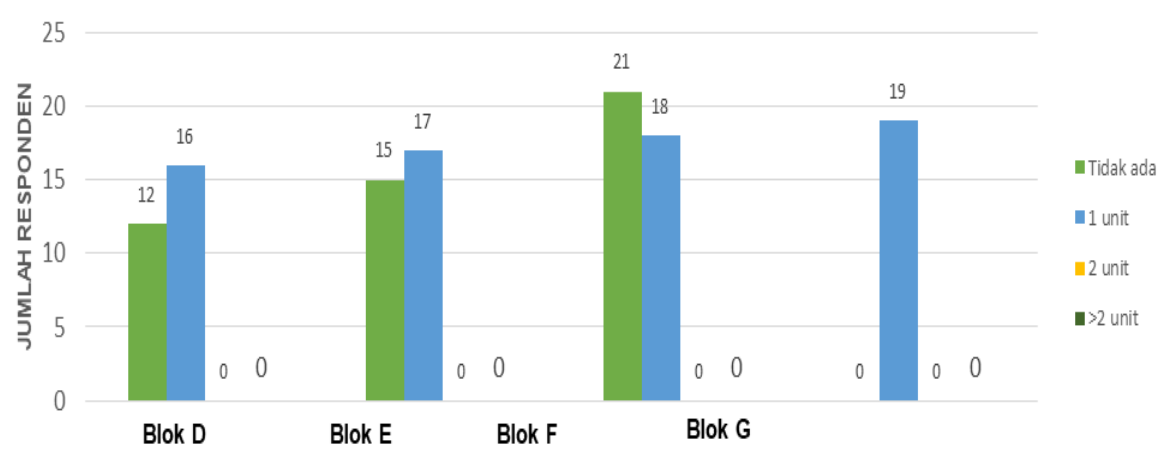

Gambar 6. Grafik Kepemilikan Kendaraan Roda 4 (empat) Mobil Pribadi

\section{Jenis pekerjaan dan Penghasilan Rata-rata Keluarga}

Berdasarkan survei menunjukkan jenis pekerjaan penduduk perumahan Taman Sudiang Indah adalah pegawai swasta, wiraswasta, dan pegawai negeri sipil, dan penghasilan rata-rata keluarga berkisar antara 1-9 (satu-sembilan) juta. 
Tabel 6. Penghasilan rata-rata Keluarga

\begin{tabular}{|c|c|c|c|c|c|c|c|c|c|}
\hline \multirow{2}{*}{ No } & \multirow{2}{*}{$\begin{array}{c}\text { Blok \& } \\
\text { tipe } \\
\text { rumah }\end{array}$} & \multicolumn{2}{|c|}{ Penhasilan Rata-Rata Keluarga } & \multicolumn{4}{c|}{ Persentase (\%) } \\
\cline { 3 - 11 } & juta & $\begin{array}{c}\mathbf{1 - 3} \\
\text { juta }\end{array}$ & $\begin{array}{c}\mathbf{7 - 9} \\
\text { juta }\end{array}$ & $\begin{array}{c}\mathbf{> 9} \\
\text { juta }\end{array}$ & $\mathbf{1 - 3}$ juta & $\mathbf{4 - 6}$ juta & $\mathbf{7 - 9}$ juta & $>$ 9 juta \\
\hline 1 & $\mathrm{D} / 36$ & 10 & 9 & 5 & 4 & 35,714 & 32,143 & 17,857 & 14,286 \\
\hline 2 & $\mathrm{E} / 36$ & 13 & 5 & 7 & 11 & 36,111 & 13,889 & 19,444 & 30,556 \\
\hline 3 & $\mathrm{~F} / 36$ & 18 & 9 & 2 & 10 & 46,154 & 23,077 & 5,128 & 25,641 \\
\hline 4 & $\mathrm{G} / 36$ & 0 & 3 & 0 & 16 & 0,000 & 15,789 & 0,000 & 84,211 \\
\hline
\end{tabular}

Hasil Tabel 6 membuktikan bahwa jumlah penghasilan rata-rata keluarga lebih 9 (Sembilan) juta rupiah mendominasi adalah blok $\mathrm{G}$ sebesar $84,211 \%$. Jumlah penghasilan rata-rata keluarga kisaran 7-9 (tujuhsembilan) juta rupiah mendominasi blok E yaitu sebesar 19,444\%. Jumlah penghasilan rata-rata keluarga kisaran 4-6 (empat-enam) juta rupiah mendominasi blok D sebesar 32,143\%. Jumlah penghasilan rata-rata keluarga kisaran 1-3 (satu-tiga) juta rupiah mendominasi adalah blok F sebesar 46,154\%.

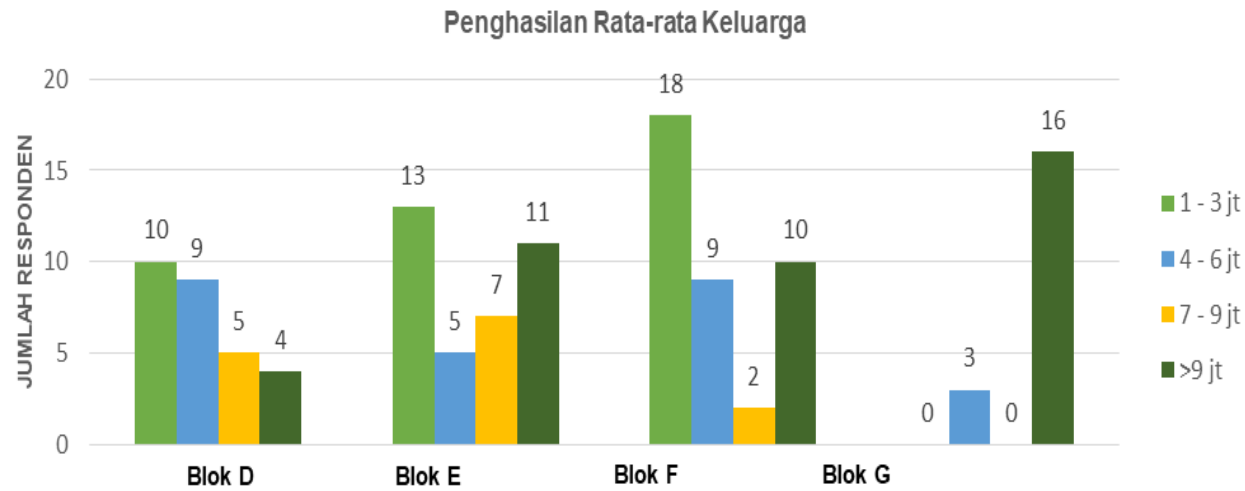

Gambar 7. Grafik Penghasilan Rata-rata Keluarga

\section{Waktu Keberangkatan Tujuan Perjalanan}

Tabel 7. Waktu Keberangkatan Menuju Tempat Kerja

\begin{tabular}{|c|c|c|c|c|c|c|c|c|c|}
\hline \multirow{2}{*}{ No. } & \multirow{2}{*}{$\begin{array}{l}\text { Blok \& } \\
\text { tipe } \\
\text { rumah }\end{array}$} & \multicolumn{4}{|c|}{ Waktu Keberangkatan Menuju Tempat Kerja } & \multicolumn{4}{|c|}{ Persentase (\%) } \\
\hline & & $\begin{array}{c}06.00- \\
07.00\end{array}$ & $\begin{array}{c}07.00- \\
08.00\end{array}$ & $\begin{array}{c}08.00- \\
09.00\end{array}$ & $\begin{array}{c}09.00- \\
10.00\end{array}$ & 06.00-07.00 & $\begin{array}{c}07.00- \\
08.00\end{array}$ & $\begin{array}{c}\text { 08.00- } \\
09.00\end{array}$ & $\begin{array}{l}09.00- \\
10.00\end{array}$ \\
\hline 1 & $\mathrm{D} / 36$ & 3 & 16 & 9 & 0 & 10,7143 & 57,143 & 32,143 & 0 \\
\hline 2 & $\mathrm{E} / 36$ & 4 & 23 & 5 & 0 & 12,500 & 71,875 & 15,625 & 0 \\
\hline 3 & $\mathrm{~F} / 36$ & 4 & 28 & 7 & 0 & 10,256 & 71,795 & 17,949 & 0 \\
\hline 4 & $\mathrm{G} / 36$ & 5 & 2 & 12 & 0 & 26,316 & 10,526 & 63,158 & 0 \\
\hline
\end{tabular}

Hasil Tabel 7 membuktikan waktu keberangkatan menuju tempat kerja antara pukul 07.00-08.00 WITA adalah waktu paling banyak digunakan anggota keluarga terdapat pada blok E sebesar 71,875\%, blok F yaitu sebesar $71,795 \%$, untuk blok D sebesar 51,143\%, dan blok G sebesar 10,526\%. 


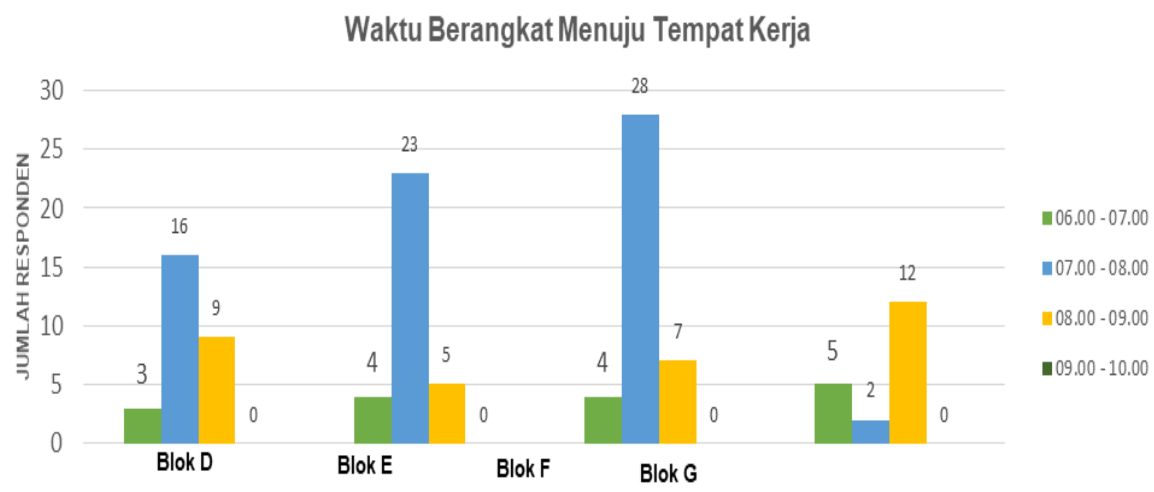

Gambar 8. Grafik Waktu Keberangkatan Menuju Tempat Kerja Kerja

Hasil Tabel 9 membuktikan waktu keberangkatan ke sekolah atau kampus, pukul 06.00-07.00 WITA digunakan oleh anggota keluarga di perumahan Taman Sudiang Indah. Blok G sebesar 100\%, blok F sebesar $87,179 \%$, blok E sebesar 78,125\%, dan blok D sebesar 75\%. Hal ini menunjukkan pada pukul 06.00-07.00 WITA merupakan jam paling dipilih menuju ke sekolah/kampus. Hasil ini sesuai jadwal responden waktu rutin keberangkatan ke sekolah atau kampus sebelum dilaksanakan belajar di rumah karena pandemi Covid 19.

Tabel 8. Waktu Keberangkatan Menuju Sekolah/kampus

\begin{tabular}{|c|c|c|c|c|c|c|c|c|c|}
\hline \multirow{2}{*}{ No. } & \multirow{2}{*}{$\begin{array}{l}\text { Blok \& } \\
\text { tipe } \\
\text { rumah }\end{array}$} & \multicolumn{4}{|c|}{$\begin{array}{c}\text { Waktu Keberangkatan Menuju } \\
\text { Sekolah/Kampus }\end{array}$} & \multicolumn{4}{|c|}{ Persentase (\%) } \\
\hline & & $\begin{array}{c}06.00- \\
07.00\end{array}$ & $\begin{array}{c}\text { 07.00- } \\
08.00\end{array}$ & $\begin{array}{c}08.00- \\
09.00\end{array}$ & $\begin{array}{c}09.00- \\
10.00\end{array}$ & $\begin{array}{c}06.00- \\
07.00\end{array}$ & $\begin{array}{c}\text { 07.00- } \\
\text { 08.00 }\end{array}$ & $\begin{array}{c}08.00- \\
09.00\end{array}$ & $\begin{array}{c}09.00- \\
10.00\end{array}$ \\
\hline 1 & $\mathrm{D} / 36$ & 21 & 7 & 0 & 0 & 75 & 25 & 0 & 0 \\
\hline 2 & $\mathrm{E} / 36$ & 25 & 7 & 0 & 0 & 78,125 & 21,875 & 0 & 0 \\
\hline 3 & $\mathrm{~F} / 36$ & 34 & 5 & 0 & 0 & 87,179 & 12,821 & 0 & 0 \\
\hline 4 & $\mathrm{G} / 36$ & 19 & 0 & 0 & 0 & 100 & 0 & 0 & 0 \\
\hline
\end{tabular}

Waktu Berangkat Menuju Sekolah/Kampus

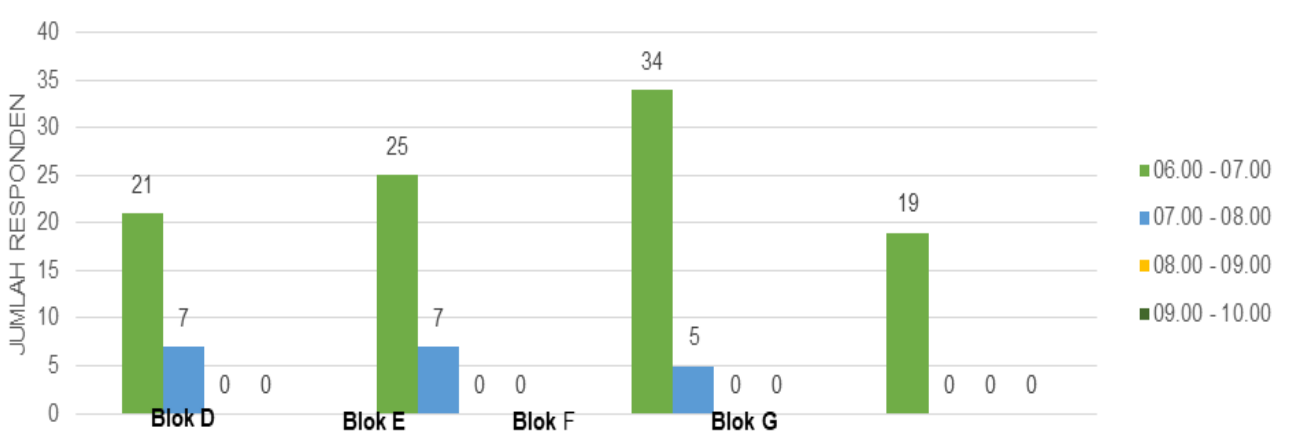

Gambar 9. Grafik Waktu Keberangkatan Menuju Sekolah/Kampus

\section{Kendaraan Dominan Digunakan}

Berdasarkan hasil survei telah pilihan kendaraan responden melakukan perjalanan terlihat sepeda motor menjadi pilihan terbanyak bekerja dengan persentase $63,559 \%$. Hasil persentase pilihan kendaraan responden melakukan perjalanan menggunakan mobil pribadi $38,136 \%$, hasil persentase pilihan kendaraan responden melakukan perjalanan menggunakan angkutan umum dan ojek online Grab/Gojek sebesar $0 \%$ atau tidak ada. 


\section{Jenis kendaraan apa yang selalu Anda gunakan untuk tujuan ke tempat kerja}

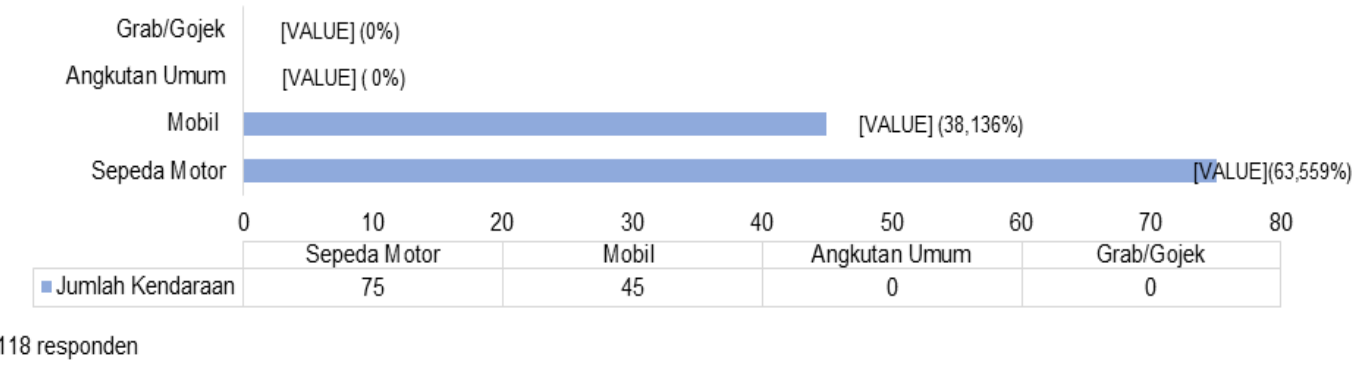

Gambar 9. Grafik Kendaraan Ke Tempat Kerja

Berdasarkan hasil dari survei pilihan kendaraan responden melakukan perjalanan terlihat sepeda motor menjadi pilihan terbanyak bersekolah/kuliah dengan hasil persentase $78,814 \%$. Hasil persentase kendaraan responden melakukan perjalanan menggunakan jasa ojek online Grab/Gojek sebesar 14,407\%, hasil persentase pilihan kendaraan responden melakukan perjalanan menggunakan angkutan umum sebesar $11,017 \%$, dan hasil persentase pilihan kendaraan responden melakukan perjalanan menggunakan mobil pribadi sebesar $8,475 \%$.

Jenis kendaraan yang selalu Anda gunakan untuk tujuan ke sekolah atau kampus

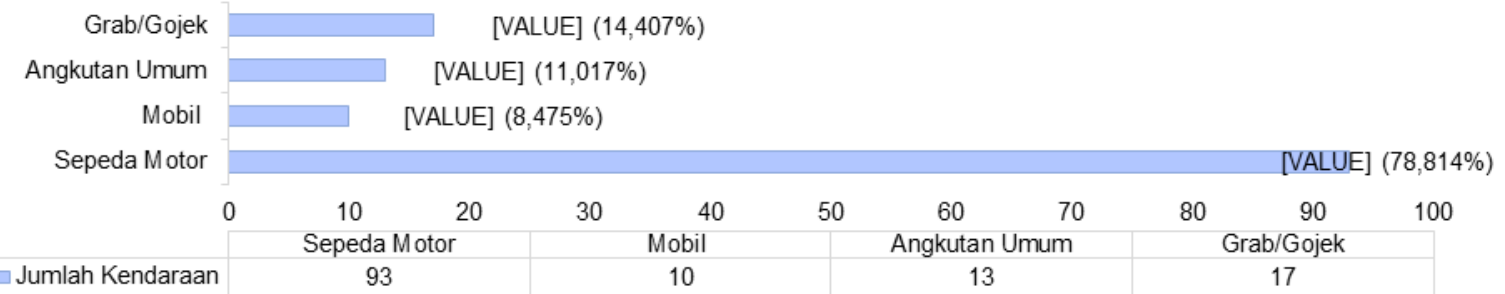

118 responden

\section{Gambar 10. Grafik Kendaraan Menuju Sekolah/Kampus}

\section{ANALISIS KORELASI}

Tabel 9. Matriks Korelasi

\begin{tabular}{|c|c|c|c|c|c|c|c|c|}
\hline & Variabel & $\mathrm{X} 1$ & $\mathrm{X} 2$ & X3 & $\mathrm{X} 4$ & $\mathrm{X} 5$ & X6 & $\mathrm{Y}$ \\
\hline \multirow[t]{2}{*}{$\mathrm{X} 1$} & $\begin{array}{l}\text { Pearson } \\
\text { Correlation }\end{array}$ & 1 & $-.216^{*}$ & .062 & -.004 & $.196^{*}$ & $.222^{*}$ & -.012 \\
\hline & Sig. (2-tailed) & & .019 & .502 & .962 & .033 & .016 & .895 \\
\hline \multirow[t]{2}{*}{$\mathrm{X} 2$} & $\begin{array}{l}\text { Pearson } \\
\text { Correlation }\end{array}$ & & 1 & .049 & -.066 & -.080 & -.175 & -.087 \\
\hline & Sig. (2-tailed) & & & .595 & .480 & .390 & .059 & .349 \\
\hline \multirow[t]{2}{*}{$\mathrm{X} 3$} & $\begin{array}{l}\text { Pearson } \\
\text { Correlation }\end{array}$ & & & 1 & $.747^{* *}$ & $-.214^{*}$ & .053 & $-.239^{* *}$ \\
\hline & Sig. (2-tailed) & & & & .000 & .020 & .568 & .009 \\
\hline \multirow[t]{2}{*}{$\mathrm{X} 4$} & $\begin{array}{l}\text { Pearson } \\
\text { Correlation }\end{array}$ & & & & 1 & -.140 & $.255^{* *}$ & -.015 \\
\hline & Sig. (2-tailed) & & & & & .131 & .005 & .875 \\
\hline
\end{tabular}


Volume 3 Issue 4, Desember 2021

\begin{tabular}{|c|c|c|c|c|}
\hline \multirow[t]{2}{*}{$\mathrm{X} 5$} & $\begin{array}{l}\text { Pearson } \\
\text { Correlation }\end{array}$ & 1 & -.087 & $.320^{* *}$ \\
\hline & Sig. (2-tailed) & & .352 & .000 \\
\hline \multirow[t]{2}{*}{ X6 } & $\begin{array}{l}\text { Pearson } \\
\text { Correlation }\end{array}$ & & 1 & $.258^{* *}$ \\
\hline & Sig. (2-tailed) & & & .005 \\
\hline \multirow[t]{2}{*}{$\mathrm{Y}$} & $\begin{array}{l}\text { Pearson } \\
\text { Correlation }\end{array}$ & & & 1 \\
\hline & Sig. (2-tailed) & & & \\
\hline
\end{tabular}

Berdasarkan Tabel 10, diketahui secara simultan tingkat korelasi jumlah anggota keluarga (X1) sangat kuat, jumlah kepemilikan kendaraan roda 2 (dua) sepeda motor (X2) rendah, jumlah kepemilikan kendaraan roda 4 (empat) mobil pribadi (X3) rendah, penghasilan rata-rata keluarga (X4) rendah, jumlah anggota keluarga bekerja (X5) sangat kuat, jumlah anggota keluarga bersekolah/kampus (X6) sangat kuat terhadap jumlah bangkitan (Y). disimpulkan taraf nyata 5\% semua variabel independen berkorelasi signifikan terhadap variabel dependen.

Tabel 10. Estimasi Model Regresi

\begin{tabular}{|c|c|c|c|}
\hline Variabel & Koefisien & t Hitung & p value \\
\hline (Konstanta) & 1,273 & 3,397 & 0,001 \\
\hline $\mathrm{X} 1$ & $-0,084$ & $-1,305$ & 0,195 \\
\hline $\mathrm{X} 2$ & $-0,012$ & $-0,097$ & 0,923 \\
\hline $\mathrm{X} 3$ & $-0,385$ & $-2,498$ & 0,014 \\
\hline $\mathrm{X} 4$ & 0,095 & 1,543 & 0,126 \\
\hline $\mathrm{X} 5$ & 0,371 & 3,722 & 0 \\
\hline X6 & 0,273 & 3,021 & 0,003 \\
\hline $\mathrm{R}^{2}$ & $=0,253$ & $=6,277$ & $p$ value $=0,000$ \\
\hline
\end{tabular}

Persamaan regresi dari hasil estimasi analisis regresi linier berganda : $Y=1,2730-0,084 X_{1}-0,012 X_{2}-0,385$ $\mathrm{X}_{3}+0,095 \mathrm{X}_{4}+0,371 \mathrm{X}_{5}+0,273 \mathrm{X}_{6}$

\section{PEMBAHASAN}

1. Berdasarkan survei dilakukan (lihat gambar 9 dan 10) terhadap pilihan kendaraan responden melakukan perjalanan terlihat sepeda motor menjadi pilihan terbanyak bekerja $(63,559 \%)$ dan bersekolah/kampus $(78,814 \%)$.

2. Hasil analisis data menggunakan SPSS (Statistic Program for Special Science) diperoleh model bangkitan perjalanan di perumahan Taman Sudiang Indah: $\mathrm{Y}=1,2730+0,095 \mathrm{X}_{4}+0,371 \mathrm{X}_{5}+0,273 \mathrm{X}_{6}$

a. Koefisien $\mathrm{X}_{4}$ sebesar 0,095 , artinya setiap penghasilan rata-rata setiap keluarga berpotensi meningkatkan terjadinya penambahan jumlah bangkitan perjalanan sebesar 0,095 kali perjalanan/hari.

b. Koefisien $\mathrm{X}_{5}$ sebesar 0,371, artinya setiap penambahan 1 (satu) jumlah anggota keluarga bekerja berpotensi meningkatkan jumlah bangkitan perjalanan sebesar 0,371 kali perjalanan/hari.

c. Koefisien $\mathrm{X}_{6}$ sebesar $0,273 \%$, artinya setiap anggota keluarga bersekolah/kampus berpotensi meningkatkan jumlah bangkitan perjalanan sebesar 0,273 kali perjalanan/hari.

\section{KESIMPULAN}

Berdasarkan dari hasil analisis data responden pada perumahan Taman Sudiang Indah, maka dapat diambil kesimpulan: 
1. Berdasarkan hasil penelitian diperoleh karakteristik penduduk di kompleks perumahan Taman Sudiang Indah adalah jumlah anggota keluarga, jumlah kepemilikan kendaraan roda 2 (dua) sepeda motor, jumlah kepemilikan kendaraan roda 4 (empat) mobil pribadi, penghasilan rata - rata keluarga, jumlah anggota keluarga bekerja, jumlah anggota keluarga bersekolah/kampus.

2. Hasil pengujian hipotesis dominan diambil kesimpulan terdapat pengaruh positif dan signifikan variabel jumlah kepemilikan kendaraan roda 2 (dua) sepeda motor (X2), jumlah anggota keluarga bekerja (X5), dan jumlah anggota keluarga bersekolah/Kampus (X6) terhadap jumlah bangkitan (Y). Sedangkan sisanya yaitu variabel jumlah anggota keluarga (X1), jumlah kepemilikan kendaraan roda 4 (empat) mobil pribadi (X3), dan penghasilan rata-rata keluarga (X4) berpengaruh tidak signifikan terhadap jumlah bangkitan (Y).

3. Hasil analisis data menggunakan SPSS (Statistic Program for Special Science) diperoleh model bangkitan perjalanan di perumahan Taman Sudiang Indah: $\mathrm{Y}=1,2730+0,095 \mathrm{X}_{4}+0,371 \mathrm{X}_{5}+0,273 \mathrm{X}_{6}$

a. Konstanta regresi sebesar 1,2730 berarti perumahan Taman Sudiang Indah menghasilkan bangkitan perjalanan 1,2730/hari.

b. Koefisien $\mathrm{X}_{4}$ sebesar 0,095 berarti setiap perjalanan yang dibangkitkan oleh masyarakat perumahan Taman Sudiang Indah akan menambah biaya transportasi sebesar 0,095/hari.

c. Koefisien $\mathrm{X}_{5}$ sebesar 0,371 berarti jumlah pergerakan anggota keluarga bekerja pada perumahan Taman Sudiang Indah menghasilkan 0,371/hari.

d. Koefisien $\mathrm{X}_{6}$ sebesar 0,273 berarti jumlah pergerakan anggota keluarga bersekolah/kampus pada perumahan Taman Sudiang Indah menghasilkan 0,273/hari.

\section{DAFTAR PUSTAKA}

[1] J. Khisty C. dan B. K. Lall, Dasar - Dasar Rekayasa Transportasi, 3 ed., vol. 1. Jakarta: Erlangga, 2005.

[2] Badan Pusat Statistik, Makassar dalam Angka 2020. Kota Makassar: BPS Kota Makassar, 2020.

[3] R. Rachman, H. Parung, S. Trisutomo, dan N. Ali, "Study On The Travel Behavior Of Worker Living In The Makassar Suburban,” J. Civ. Eng. Technol. IAEME Publ., vol. 8, no. 6, hlm. 986-995, 2017.

[4] F. Miro, Perencanaan Transportasi untuk Mahasiswa, Perencana dan Praktisi. Jakarta: Erlangga, 2005.

[5] R. Rachman, "Transportasi," dalam Dampak Pandemi Covid-19 Dalam Multi Perspektif, Makassar: Tohar Media, 2021, hlm. 67-92.

[6] J. D. Ortuzar dan L. G. Willumsen, Modelling Transport. Chichester: John Willey and Sons., 2001.

[7] Sugiono, Statistik untuk Penelitian. Bandung: CV. Alfabeta, 2002.

[8] R. Rachman, H. Parung, S. Sutomo Tri, dan N. Ali, "Model Bangkitan Perjalanan Komuter Pinggiran Kota Makassar (Studi Kasus Perumahan Tirasa Pratama)," dalam Prosiding Konfrensi Nasional Pascasarjana Teknik Sipil (KNPTS), Bandung, 2013, hlm. 301-307.

[9] R. Rachman, M. I. Ramli, N. Ali, dan H. Parung, "Studi Bangkitan Pergerakan Komuter Pada Perumahan Berlokasi Di Pinggiran Kota Makassar," dalam Prosiding Seminar Nasional IX - 2013 Teknik Sipil ITS, Surabaya, vol. IX, hlm. 1-8.

[10] S. N. Putra, R. Rachman, dan M. D. M. Palinggi, "Analisis Bangkitan Perjalanan Berbasis Rumah Tangga pada Perumahan Bumi Tamanlarea Permai Kota Makassar,” Paulus Civ. Eng. J., vol. 2, no. 1, hlm. 38-45, 2020.

[11] J. M. R. Kaho, J. H. Frans, dan E. E. Hangge, "Bangkitan Perjalanan Penduduk di Kecamatan Alak Kota Kupang," J. Tek. Sipil, vol. 8, no. 1, hlm. 1-8, 2019.

[12] F. Helmi, N. Fadhly, dan Y. Darma, "Bangkitan Perjalanan Rumah Tangga Di Kecamatan Darussalam Kabupaten Aceh Besar,” J. Skripsi Rekayasa Sipil Dan Perencana, vol. 2, no. 1, hlm. 68-77, 2019. 